\title{
Analisis Kondisi Pemberdayaan Gender di Indonesia Tahun 2020 dengan Agglomerative Hierarchical Clustering dan Biplot
}

\author{
(Analysis of Indonesia's Gender Empowerment Conditions in 2020 with Agglomerative \\ Hierarchical Clustering and Biplot) \\ Dina Salsabila $^{1 *}$, Muhammad Yunus Hendrawan ${ }^{2}$ \\ ${ }^{1,2}$ Politeknik Statistika STIS \\ Jalan Otto Iskandardinata No.64C, Jatinegara, Kota Jakarta Timur, DKI Jakarta, 13330 \\ E-mail: 221709635@stis.ac.id
}

\begin{abstract}
ABSTRAK
Pemberdayaan gender menjadi salah satu agenda penting dalam tujuan pembangunan berkelanjutan, baik dalam level nasional maupun internasional. Penelitian ini bertujuan untuk mengetahui kondisi pemberdayaan gender di Indonesia tahun 2020. Data yang digunakan adalah Indeks Pemberdayaan Gender (IDG) dan data tiga komponen pembentuk IDG yang bersumber dari BPS. Penelitian ini melakukan clustering IDG di Indonesia dengan metode agglomerative hierarchical clustering dan biplot. Dari hasil clustering IDG didapatkan tiga klaster IDG tahun 2020 berdasarkan kesamaan karakteristik komponen pembentuk IDG. Klaster pertama terdiri dari 3 provinsi yang memiliki nilai komponen IDG lebih rendah jika dibandingkan dengan kelompok lain, terutama dari sisi komponen keterwakilan perempuan dalam parlemen. Klaster kedua terdiri dari 5 provinsi yang memiliki nilai tinggi pada komponen keterwakilan perempuan dalam parlemen. Adapun klaster ketiga terdiri dari 26 provinsi yang memiliki nilai sedang pada ketiga komponen IDG. Hasil clustering ini dapat menjadi pertimbangan bagi pemerintah dalam menentukan kebijakan terkait pemberdayaan gender di Indonesia.
\end{abstract}

Kata kunci: gender, IDG, agglomerative hierarchical clustering, biplot

\section{ABSTRACT}

Gender empowerment has become one of important agenda in sustainable development goals, both at the national and international levels. This research aims to determine the condition of gender empowerment in Indonesia in 2020. The data used are the Gender Empowerment Measurement (GEM) and data on the three components that make up the GEM sourced from BPS. This study conducted GEM clustering in Indonesia using agglomerative hierarchical clustering and biplot methods. The results of GEM clustering obtained three GEM clusters in 2020 based on the characteristics of the components that make up GEM. The first cluster consisting of 3 provinces has a low GEM component value compared to other groups, especially in women's representation in parliament. The second cluster consists of 5 provinces with high scores on women's representation in parliament. The third cluster consists of 26 provinces that have average scores on the three components of the GEM. The results of this clustering can be a consideration for the government in determining policies related to gender empowerment in Indonesia.

Keywords: gender, GEM, agglomerative hierarchical clustering, biplot

\section{PENDAHULUAN}

Indonesia berupaya untuk mencapai Tujuan Pembangunan Berkelanjutan (TPB) atau Sustainable Development Goals (SDGs) sebagai prioritas dalam pembangunan nasional. TPB/SDGs adalah pembangunan yang mendukung peningkatan kesejahteraan ekonomi, sosial, dan lingkungan hidup secara berkesinambungan. Salah satu isu multidimensi dari ketujuh belas tujuan dalam Tujuan Pembangunan Berkelanjutan dan tercantum pada hampir seluruh TPB/SDGs adalah isu mengenai gender. Isu gender ini secara eksplisit termuat dalam tujuan kelima TPB/SDGs, "mencapai kesetaraan gender dan memberdayakan perempuan" (Bappenas, 2019). Kemajuan nasional tidak dapat dicapai tanpa terciptanya kesetaraan gender. Penting bagi Indonesia untuk memastikan bahwa semua diskriminasi atas dasar gender diakhiri untuk mencapai kemajuan nasional melalui pembangunan berkelanjutan (KPPA, 2020).

Gender adalah suatu istilah yang digunakan oleh masyarakat untuk menggambarkan peran, perilaku, sifat, sikap, dan atribut yang berbeda antara laki-laki dan perempuan (Bappenas, 2019). World Health Organization (WHO) menyebutkan bahwa gender merujuk pada peran, perilaku, kegiatan, atribut dan peluang yang dianggap sesuai oleh masyarakat untuk perempuan dan laki-laki. Gender berbeda dengan jenis kelamin secara 
biologis. Gender cenderung mempengaruhi berbagai peran, tanggung jawab, pembagian kerja, dan kedudukan antara perempuan dan laki-laki berdasarkan sifat yang dianggap pantas menurut adat istiadat, norma, kepercayaan, atau kebiasaan masyarakat.

Dalam pembangunan manusia, kesenjangan dan kesetaraan gender menjadi sangat penting untuk diperhatikan. Kesenjangan gender adalah kondisi yang tidak setara atau tidak seimbang terkait gender yang diakibatkan oleh budaya, sistem dan struktur sosial. Adapun kesetaraan gender adalah suatu kondisi yang adil dan setara bagi laki-laki dan perempuan untuk memiliki hak dan kesempatan yang sama. Kesetaraan gender diwujudkan dalam kondisi di mana tidak terdapat diskriminasi antara laki-laki dan perempuan serta terjadi ketika pembagian dan siklus sosial laki-laki dan perempuan sama, seimbang dan harmonis (Diana, 2018).

Untuk mengukur capaian kesetaraan gender dan pemberdayaan perempuan dapat dilihat melalui indikator capaian pembangunan berbasis gender, yaitu Indeks Pembangunan Gender (IPG) dan Indeks Pemberdayaan Gender (IDG). IPG mengukur kesenjangan pembangunan antara laki-laki dan perempuan, sedangkan IDG mengukur kesetaraan peran antara perempuan dan laki-laki dalam ekonomi, politik dan manajerial atau pengambilan keputusan. IDG menjadi penting untuk dihitung karena merupakan salah satu indikator utama dalam mengukur keberhasilan pembangunan manusia khususnya pada ketiga bidang tersebut. IDG dihitung dari rata-rata aritmetika dari tiga komponen pembentuknya yaitu keterwakilan perempuan dalam parlemen, perempuan sebagai tenaga profesional dan sumbangan pendapatan perempuan (KPPA, 2020).

Sejak Maret 2020 hingga hari ini, Indonesia mengalami pandemi Covid-19. Pandemi Covid-19 telah berdampak besar pada bidang kesehatan, ekonomi, dan sosial di Indonesia. Akibat dari pandemi Covid-19 juga terlihat dari adanya penurunan drastis mata pencaharian secara umum, dan dapat mengganggu kemajuan yang telah dicapai selama ini (KPPA, 2020). Perubahan keadaan ini juga mempengaruhi kesetaraan gender, sehingga perempuan lebih sulit dalam menghadapi Covid-19 dibandingkan laki-laki, baik dari segi kesehatan maupun ekonomi (Chairani, 2020). Pandemi Covid-19 memiliki implikasi ekonomi yang berlaku bagi perempuan maupun laki-laki, namun perekonomian pada perempuan lebih rentan untuk terdampak karena perempuan memiliki pendapatan dan tabungan yang rendah serta tidak memiliki proteksi yang memadai (Badan Pusat Statistik, 2020). Sejalan dengan itu, Komisi Eropa juga melaporkan bahwa pandemi Covid-19 berdampak terhadap kesetaraan gender, baik dari sisi partisipasi perempuan dalam pasar tenaga kerja maupun kesetaraan dalam pengambilan keputusan pada bidang ekonomi dan politik (European Commission, 2021).

Berdasarkan permasalahan tersebut, artikel ini bertujuan untuk mendapatkan gambaran umum terkait kondisi pemberdayaan gender pada masa pandemi Covid-19 dilihat dari tiga komponen penyusun IDG. Selain itu, pada penelitian ini akan dilakukan pengelompokan (clustering) terhadap wilayah provinsi di Indonesia berdasarkan tiga komponen penyusun Indeks Pemberdayaan Gender (IDG). Pengelompokan ini bertujuan untuk melihat kondisi kesetaraan peran dan kemampuan antara perempuan dan laki-laki dalam aspek ekonomi, politik dan pengambilan keputusan pada tiap provinsi di Indonesia. Hasil pengelompokan tersebut akan menghasilkan kelompok-kelompok provinsi yang memiliki karakteristik komponen IDG yang berdekatan. Sehingga penelitian ini diharapkan dapat bermanfaat bagi pemerintah dalam membuat kebijakan yang tepat terkait pemberdayaan gender di Indonesia.

Dalam melakukan studi ini, terdapat beberapa penelitian sebelumnya yang dijadikan sebagai rujukan dan referensi oleh peneliti. Diana (2018) dalam penelitiannya melakukan analisis ketimpangan gender di Provinsi Sumatera Barat menggunakan metode biplot dan mengelompokkan IDG terhadap kabupaten/kota di Sumatera Barat pada tahun 2015. Penelitian lainnya oleh Nisa (2018) yang menggunakan metode hierarchical clustering untuk menganalisis dan mengelompokkan Kabupaten/Kota di Jawa Timur berdasarkan kondisi pembangunan gender yang tidak merata. Penelitian yang menggunakan analisis biplot dan hierarchical clustering dilakukan juga oleh Agusrawati, Wibawa, Yahya dan Abapihi (2021) yang menjelaskan persebaran penyakit menular di Sulawesi Tenggara. Selain itu terdapat pula penelitian oleh Chairani (2020) yang menganalisis dampak pandemi Covid-19 terhadap kesehatan, ekonomi dan sosial dari perspektif gender di Indonesia. Penelitian Chairani (2020) menunjukkan bahwa perempuan lebih sulit dalam menghadapi pandemi Covid-19 dibandingkan dengan laki-laki, sehingga perlu adanya kebijakan yang baik agar terhindar dari masalah kesenjangan gender akibat pandemi Covid-19.

\section{METODE}

\section{Landasan Teori}

\section{Indeks Pemberdayaan Gender}

Indeks Pemberdayaan Gender (IDG) atau Gender Empowerment Measure (GEM) adalah indikator yang digunakan untuk menilai kesetaraan gender melalui partisipasi aktif perempuan di bidang ekonomi, politik dan 
manajerial atau pengambilan keputusan. Tiga komponen pembentuk IDG yaitu persentase sumbangan perempuan dalam pendapatan kerja, keterwakilan perempuan dalam parlemen, dan keterwakilan perempuan dalam pengambilan keputusan melalui indikator perempuan sebagai tenaga manajerial, profesional, administrasi, dan teknisi (Badan Pusat Statistik). Penghitungan IDG diperoleh dari rata-rata aritmetika ketiga indeks yang terdiri dari tiga komponen penyusun IDG.

Indikator yang digunakan untuk menghitung IDG berdasarkan komponen pembentuk IDG dapat dilihat pada Tabel 1 berikut.

Tabel 1. Dimensi dan indikator perhitungan Indeks Pemberdayaan Gender.

\begin{tabular}{cc}
\hline Dimensi & Indikator \\
\hline $\begin{array}{c}\text { Keterwakilan Perempuan Dalam Parlemen/KPDP } \\
\text { (Bidang Politik) }\end{array}$ & $\begin{array}{c}\text { Proporsi keterwakilan di Parlemen (DPR dan DPRD); } \\
\text { Laki-laki \& Perempuan }\end{array}$ \\
$\begin{array}{c}\text { Perempuan Sebagai Tenaga Profesional/PSTP } \\
\text { (Bidang Manajerial) }\end{array}$ & $\begin{array}{l}\text { Proporsi dari manajer, staf administrasi, pekerja } \\
\text { profesional dan teknisi; Laki-laki \& Perempuan }\end{array}$ \\
Sumbangan Pendapatan Perempuan/SPP \\
(Bidang Ekonomi)
\end{tabular}

Sumber: Badan Pusat Statistik

\section{Hierarchical Clustering}

Clustering adalah proses pengelompokan objek ke dalam sebuah klaster. Objek dalam klaster yang sama memiliki kemiripan yang tinggi dan perbedaan yang tinggi antar klaster yang berbeda. Salah satu metode yang dapat digunakan dalam clustering adalah metode hierarki. Pendeketan hierarki dimulai dengan sekelompok dua atau lebih objek yang memiliki kesamaan terbesar. Dalam hal ini, terdapat tingkatan (hierarki) yang jelas antar objek, dari yang paling mirip hingga yang paling tidak mirip (Widyadhana, Hastuti, Kharisudin, \& Fauzi, 2021). Salah satu pendekatan dari metode hierarki adalah agglomerative hierarchical clustering .

Metode agglomerative hierarchical clustering adalah teknik pengelompokan hierarki yang paling umum digunakan untuk mengelompokkan objek ke dalam sebuah klaster berdasarkan kesamaan karakteristik, dimulai dengan setiap objek dalam satu klaster yang terpisah kemudian membentuk klaster yang semakin membesar (pendekatan bottom-up) yang hasilnya dijelaskan oleh dendrogram. Dendrogram menjelaskan proses pembentukan klaster yang direpresentasikan dalam bentuk gambar sehingga dapat memudahkan pengelompokan objek-objek yang ada (Nisa, 2018). Metode agglomerative hierarchical clustering dipilih karena metode ini memiliki kelebihan dibandingkan partitioned clustering yaitu lebih fleksibel terhadap granularity dan mudah mengadaptasi berbagai ukuran kemiripan (Situngkir, Rachmawati, \& Maharani, 2013). Selain itu, metode ini memiliki kelebihan karena dapat digunakan apabila belum ada informasi jumlah klaster yang akan dipilih (Widyadhana, Hastuti, Kharisudin, \& Fauzi, 2021). Dengan melakukan pengelompokan klaster menggunakan agglomerative hierarchical clustering, penelitian ini akan mendapatkan kelompok secara hierarki untuk mengetahui kelompok provinsi di Indonesia berdasarkan komponen penyusun IDG.

\section{Data dan Sumber Data}

Data yang digunakan adalah data Indeks Pemberdayaan Gender, sumbangan pendapatan perempuan, keterwakilan perempuan dalam parlemen, dan perempuan sebagai tenaga profesional menurut provinsi di Indonesia tahun 2019 dan 2020 yang diunduh melalui website bps.go.id. Data tahun 2019 akan digunakan sebagai pembanding data 2020 untuk melihat perbedaan kondisi pemberdayaan gender sebelum dan saat terjadinya pandemi Covid-19. Data yang digunakan pada penelitian ini terlebih dahulu dilakukan preprocessing, yaitu menggabungkan data variabel penyusun IDG: $\mathrm{X} 1=$ sumbangan pendapatan perempuan (\%); X2 = keterwakilan perempuan dalam parlemen (\%); dan X3 = perempuan sebagai tenaga profesional (\%) menurut provinsi di Indonesia tahun 2019 dan 2020 ke dalam tabel baru, serta memastikan tidak ada missing value pada setiap nilai dan komponen.

\section{Metode Analisis}

Penelitian ini menggunakan aplikasi $\mathrm{R}$ Studio dengan bahasa pemrograman $\mathrm{R}$ dalam melakukan rangkaian analisis data. Dalam melihat gambaran kondisi pemberdayaan gender di Indonesia pada saat masa pandemi dilakukan analisis deskriptif terhadap data IDG pada tahun 2019 dan 2020 untuk mengetahui komponen penyusun IDG mana yang terbesar dan terkecil untuk tiap provinsi. 
Selanjutnya untuk mengelompokkan IDG tahun 2020 berdasarkan komponen pembentuk IDG dilakukan clustering dengan menggunakan agglomerative hierarchical clustering untuk melihat kedekatan dari provinsi di Indonesia pada tiap komponennya.

Adapun langkah dalam melakukan agglomerative hierachical clustering yaitu sebagai berikut.

a. Menentukan banyaknya klaster yang optimal dengan metode silhouette.

Metode silhoutte digunakan untuk mengukur seberapa baik suatu objek diposisikan dalam suatu klaster untuk melihat kualitas dan kekuatan klaster. Metode silhoutte ini memilih jumlah klaster terbaik berdasarkan nilai yang paling tinggi (Widyadhana, Hastuti, Kharisudin, \& Fauzi, 2021).

b. Melakukan clustering dengan metode average linkage sehingga terbentuk klaster dendrogram provinsi di Indonesia berdasarkan komponen IDG 2020.

Metode average linkage digunakan karena metode ini menganggap jarak antar dua klaster sebagai jarak rata-rata antara semua pasangan objek data dalam satu klaster dan semua objek di klaster lain (Fadliana, 2015).

c. Melakukan visualisasi untuk melihat distribusi klaster IDG berdasarkan komponen penyusunnya.

Kajian ini juga menggunakan metode biplot untuk melihat sebaran komponen penyusun dari IDG. Metode biplot digunakan untuk mendukung hasil pengelompokan yang telah dilakukan dengan pendekatan hierarkis aglomeratif. Metode ini bertujuan untuk meringkas informasi dari suatu matriks data yang besar ke dalam suatu plot yang berdimensi dua (Diana, 2018). Hasil analisis biplot dapat menjelaskan kedekatan antar objek yang dijadikan dasar dalam pengelompokan, variasi dari nilai variabel yang dilihat dari ukuran panjang sebuah vektor, hubungan antar variabel yang dapat dilihat dari besar sudut antar vektor variabel, dan nilai variabel pada suatu objek (Diana, 2018).

\section{HASIL DAN PEMBAHASAN}

Menurut Kementerian Pemberdayaan Perempuan dan Perlindungan Anak (2020), pemberdayaan gender merupakan salah satu indikator utama yang penting untuk menentukan keberhasilan dari sisi pembangunan manusia. Indeks Pemberdayaan Gender (IDG) sebagai indikator pemberdayaan gender di Indonesia dibuat dalam rangka untuk memberikan gambaran peran aktif perempuan dalam partisipasi politik dan pengambilan keputusan serta dalam kehidupan ekonomi. Perhitungan pada indikator IDG berfokus pada komponen keterwakilan perempuan dalam parlemen, keterwakilan perempuan dalam pengambilan keputusan sebagai tenaga profesional, dan sumbangan pendapat perempuan yang diukur dengan melihat distribusi pendapatan pada upah buruh non pertanian.

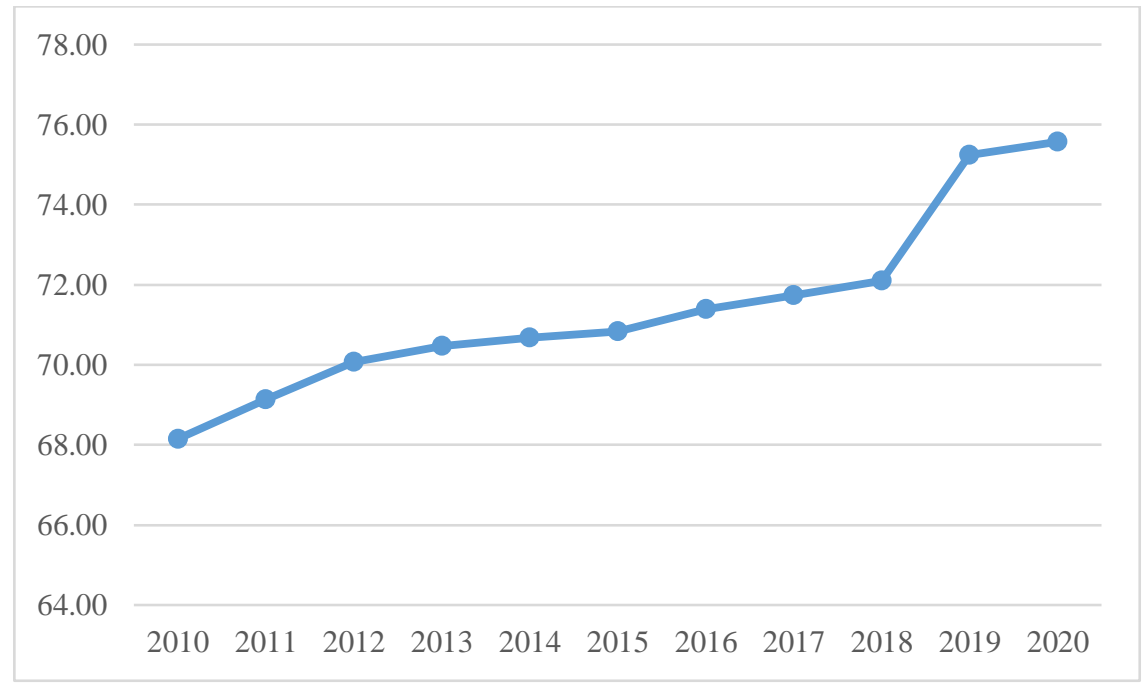

Sumber: Badan Pusat Statistik, data diolah

Gambar 1. Perkembangan IDG Indonesia Tahun 2010-2020.

Kondisi pemberdayaan gender di Indonesia pada tahun 2020 jika dilihat dari capaian IDG nasional, memiliki nilai sebesar 75,57. Seperti yang ditampilkan pada Gambar 1, sejak tahun 2010 nilai IDG Indonesia selalu meningkat dari tahun ke tahun, mulai dari 68,15 poin pada tahun 2010 hingga meningkat cukup signifikan di tahun 2019 dengan nilai 75,24 sebelum berada pada nilai 75,57 pada tahun 2020. Besaran nilai IDG nasional pada tahun 2020 tetap melanjutkan tren peningkatan nilai IDG Indonesia dalam sebelas tahun 
terakhir, meskipun persentase kenaikan yang terjadi pada tahun 2020 hanya sebesar 0,44 persen, jauh lebih kecil dibandingkan dengan persentase kenaikan nilai IDG pada tahun 2019 yang senilai 4,36 persen.

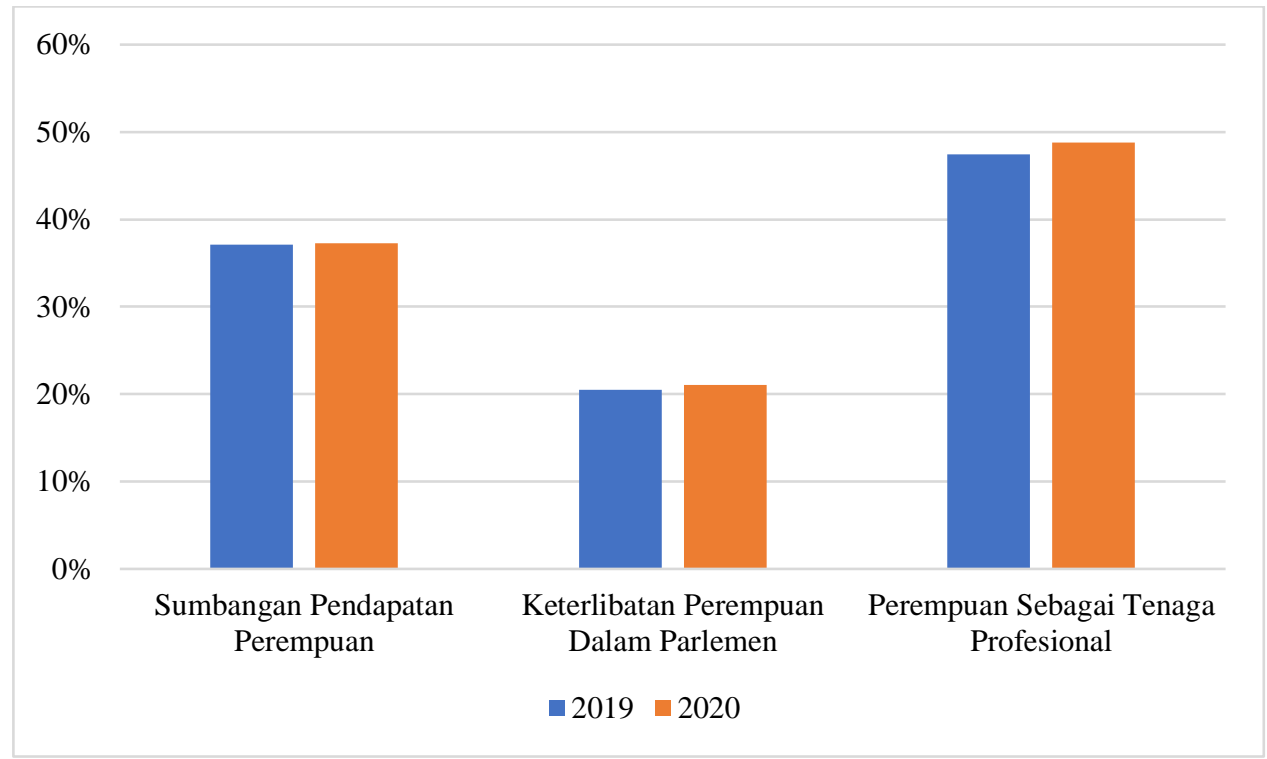

Sumber: Badan Pusat Statistik, data diolah

Gambar 2. Persentase Capaian Komponen IDG Indonesia Tahun 2019-2020.

Berdasarkan perkembangan komponen pembentuk IDG, capaian pada tahun 2020 saat terjadi pandemi Covid-19 tidak mengalami penurunan, justru tetap terjadi peningkatan pada tiap komponennya. Seperti yang dapat dilihat pada Gambar 2, peningkatan paling tinggi terdapat pada komponen perempuan sebagai tenaga profesional yang naik sebesar 1,30 persen menjadi 48,76 persen pada tahun 2020 dari sebelumnya sebesar 47,46 persen pada tahun 2019. Angka ini lebih tinggi dibandingkan kenaikan pada tahun 2019 yang hanya sebesar 0,44 persen (KPPA, 2020). Hal ini menunjukkan bahwa terlepas dari adanya pandemi Covid-19, diketahui perempuan justru mengalami peningkatan sebagai tenaga profesional untuk mengisi posisi di bidang manajerial.

Dua komponen pembentuk IDG lainnya yaitu keterwakilan perempuan dalam parlemen dan sumbangan pendapat perempuan juga mengalami peningkatan. Namun, kenaikan tersebut lebih kecil jika dibandingkan dengan kenaikan nilai IDG tiap komponen pada tahun 2019. Komponen keterwakilan perempuan dalam parlemen pada tahun 2020 meningkat 0,57 persen dari tahun 2019 menjadi sebesar 21,09 persen. Hal ini jauh berbeda dibandingkan kenaikan komponen tersebut pada tahun 2019 yang sebesar 3,20 persen (KPPA, 2020). Kenaikan yang cukup besar pada tahun 2019 disebabkan oleh adanya pemilihan umum yang menghasilkan perempuan banyak terpilih untuk masuk ke dalam parlemen dan berkontribusi di bidang politik. Adapun komponen sumbangan pendapatan perempuan naik sebesar 0,16 persen pada tahun 2020. Angka tersebut lebih kecil dibandingkan kenaikan pada tahun 2019 sebesar 0,40 persen (KPPA, 2020). Hal ini selaras dengan laporan BPS yang menyatakan perempuan lebih rentan terkena dampak pandemi Covid-19 dengan kehilangan pekerjaan pada berbagai sektor (Badan Pusat Statistik, 2020).

Jika capaian IDG Indonesia dilihat pada tingkat provinsi, nilai IDG antar provinsi di Indonesia pada tahun 2020 memperlihatkan masih terdapat kesenjangan pemberdayaan gender dalam hal pembangunan antar wilayah di Indonesia. Pada tahun 2020, hanya terdapat lima provinsi yang memiliki nilai capaian IDG di atas nilai capaian IDG nasional yang sebesar 75,57 yaitu Provinsi Kalimantan Tengah, Sulawesi Utara, Maluku Utara, Sulawesi Selatan, dan Sulawesi Tengah, sedangkan 29 provinsi lainnya masih memiliki capaian nilai IDG di bawah nilai IDG nasional. Ringkasan terkait dengan capaian IDG di lima provinsi dengan nilai IDG tertinggi dan terendah pada tahun 2020 dapat dilihat pada Tabel 2 berikut. 
Tabel 2. Capaian IDG di Lima Provinsi dengan IDG Tertinggi dan Terendah beserta komponen pembentuknya 2019-2020.

\begin{tabular}{|c|c|c|c|c|c|c|c|c|c|c|}
\hline \multirow[t]{2}{*}{ Provinsi } & \multicolumn{2}{|c|}{ Skor IDG } & \multicolumn{2}{|c|}{$\begin{array}{l}\text { Sumbangan } \\
\text { Pendapatan } \\
\text { Perempuan }\end{array}$} & \multicolumn{2}{|c|}{$\begin{array}{c}\text { Keterwakilan } \\
\text { Perempuan } \\
\text { Dalam Parlemen }\end{array}$} & \multicolumn{2}{|c|}{$\begin{array}{c}\text { Perempuan } \\
\text { Sebagai Tenaga } \\
\text { Profesional }\end{array}$} & \multicolumn{2}{|c|}{ Peringkat IDG } \\
\hline & 2019 & 2020 & 2019 & 2020 & 2019 & 2020 & 2019 & 2020 & 2019 & 2020 \\
\hline \multicolumn{11}{|c|}{ IDG Tertinggi 2020} \\
\hline $\begin{array}{l}\text { Kalimantan } \\
\text { Tengah }\end{array}$ & 83,20 & 82,41 & 33,40 & 33,63 & 35,56 & 33,33 & 45,35 & 46,12 & 1 & 1 \\
\hline Sulawesi Utara & 79,10 & 78,98 & 32,39 & 32,50 & 28,89 & 29,27 & 50,95 & 53,59 & 2 & 2 \\
\hline Maluku Utara & 77,50 & 77,28 & 36,49 & 36,75 & 26,67 & 26,67 & 46,63 & 46,84 & 3 & 3 \\
\hline $\begin{array}{l}\text { Sulawesi } \\
\text { Selatan }\end{array}$ & 76,01 & 76,32 & 32,44 & 32,55 & 27,71 & 28,40 & 53,02 & 54,47 & 4 & 4 \\
\hline $\begin{array}{c}\text { Sulawesi } \\
\text { Tengah }\end{array}$ & 74,49 & 75,78 & 30,87 & 31,10 & 24,44 & 26,67 & 48,93 & 52,84 & 8 & 5 \\
\hline \multicolumn{11}{|c|}{ IDG Terendah 2020} \\
\hline Papua Barat & 61,52 & 62,17 & 27,65 & 27,82 & 14,29 & 14,29 & 39,14 & 41,49 & 30 & 30 \\
\hline Kep. Riau & 61,59 & 62,02 & 28,61 & 28,83 & 11,11 & 11,11 & 43,16 & 46,12 & 29 & 31 \\
\hline $\begin{array}{c}\text { Sumatera } \\
\text { Barat }\end{array}$ & 59,09 & 58,28 & 37,51 & 37,57 & 4,62 & 4,62 & 55,36 & 58,97 & 32 & 32 \\
\hline $\begin{array}{l}\text { Kep. Bangka } \\
\text { Belitung }\end{array}$ & 52,96 & 53,03 & 26,84 & 26,89 & 4,44 & 4,44 & 53,15 & 51,70 & 33 & 33 \\
\hline $\begin{array}{c}\text { Nusa Tenggara } \\
\text { Barat }\end{array}$ & 51,91 & 51,96 & 32,91 & 33,11 & 1,54 & 1,56 & 45,05 & 45,95 & 34 & 34 \\
\hline
\end{tabular}

Pada tahun 2020 saat terjadi pandemi Covid-19 pada seluruh provinsi di Indonesia, capaian ranking IDG pada tiap provinsi tidak jauh berbeda dengan tahun 2019 sebelum adanya pandemi Covid-19, meskipun tiga dari lima provinsi teratas sebenarnya mengalami penurunan nilai IDG pada tahun 2020. Provinsi Kalimantan Tengah masih tetap menjadi provinsi dengan capaian IDG tertinggi di Indonesia pada tahun 2020 dengan nilai sebesar 82,41 poin, diikuti dengan Provinsi Sulawesi Utara dengan nilai sebesar 78,98 dan Provinsi Maluku Utara dengan nilai sebesar 77,28. Provinsi Sulawesi Selatan menempati posisi empat capaian IDG tertinggi di Indonesia dengan nilai sebesar 76,32 dan Provinsi Sulawesi Tengah yang pada tahun 2019 berada pada peringkat 8 naik menjadi peringkat 5 dengan capaian IDG tertinggi pada tahun 2020 dengan nilai sebesar 75,78 .

Sama halnya dengan peringkat provinsi dengan IDG tertinggi nasional pada tahun 2020, peringkat provinsi dengan IDG terendah pada tahun 2020 juga tidak mengalami banyak perubahan dengan kondisi pada tahun 2019. Meskipun mengalami sedikit peningkatan nilai pada tahun 2020, Provinsi Nusa Tenggara Barat masih menjadi provinsi dengan capaian IDG terendah secara nasional yakni sebesar 51,96 poin. Sama halnya dengan Provinsi Kep. Bangka Belitung yang tetap menjadi provinsi dengan peringkat terendah kedua dengan nilai sebesar 53,03 dan Provinsi Sumatera Barat serta Provinsi Papua Barat yang menempati posisi terendah ketiga dan kelima dengan nilai capaian IDG masing-masing sebesar 58,28 dan 62,17. Perubahan terjadi pada peringkat empat terendah pada tahun 2020 dengan capaian nilai IDG 62,02 poin, ditempati oleh Provinsi Kep. Riau yang sebelumnya menempati peringkat terendah keenam pada tahun 2019.

Kesenjangan gender antar provinsi tersebut dapat disebabkan oleh berbagai permasalahan pada masyarakat yang saling berkaitan satu sama lain seperti adanya perbedaan karakteristik penduduk, kondisi sosial budaya dan ekonomi, serta implementasi kebijakan pada setiap daerah yang berbeda-beda (KPPA, 2020). Selanjutnya peneliti akan melakukan clustering untuk melihat gambaran kondisi pemberdayaan gender di Indonesia berdasarkan provinsi. Clustering ini dilakukan untuk melihat pengelompokan provinsi di Indonesia berdasarkan nilai IDG dan dilihat pula pengelompokannya berdasarkan komponen penyusun IDG.

Dalam melakukan pengelompokan nilai IDG di Indonesia, perlu menentukan banyaknya jumlah klaster yang akan digunakan. Penentuan jumlah klaster dilakukan dengan metode Silhoutte yang hasilnya dapat dilihat pada Gambar 3. 


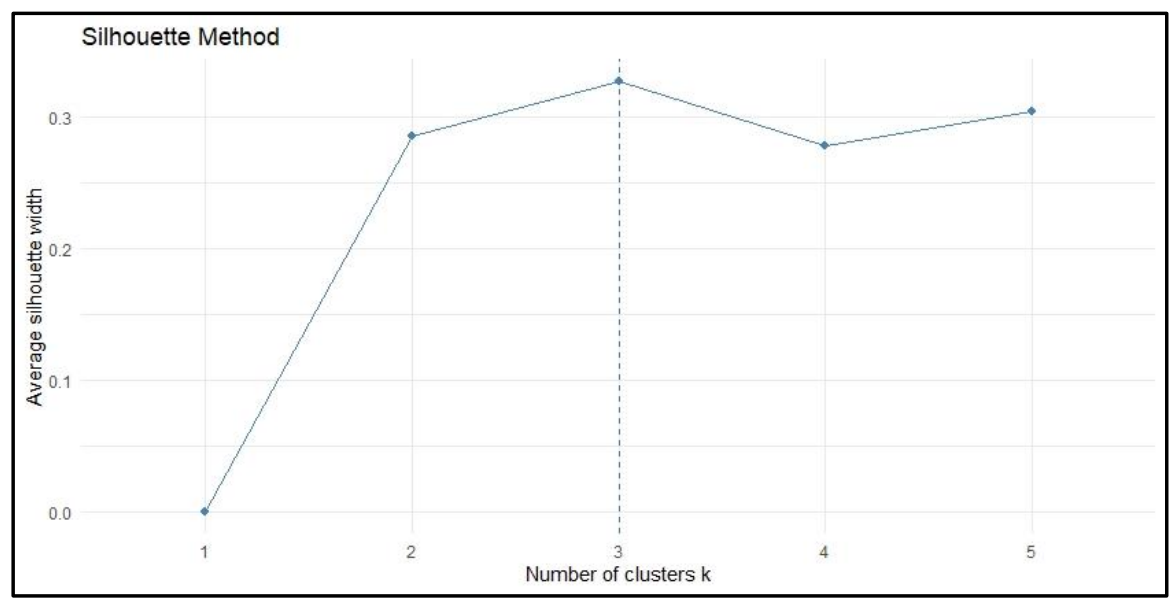

Gambar 3. Hasil Penentuan K-Cluster Optimal dengan Silhouette Method.

Seperti yang terlihat pada grafik di atas, hasil penentuan jumlah klaster yang optimal adalah tiga, karena memiliki nilai tertinggi dibandingkan dengan nilai dari jumlah klaster lainnya. Setelah didapatkan jumlah klaster optimal yang akan digunakan untuk melakukan pengelompokan, maka dilakukan clustering pada data IDG untuk setiap provinsi di Indonesia. Proses pengelompokan dilakukan dengan metode hierarki dan menggunakan metode average linkage dalam pengukuran jaraknya. Hasil klaster IDG berdasarkan komponen penyusunnya pada provinsi di Indonesia dapat dilihat pada dendrogram di bawah ini.

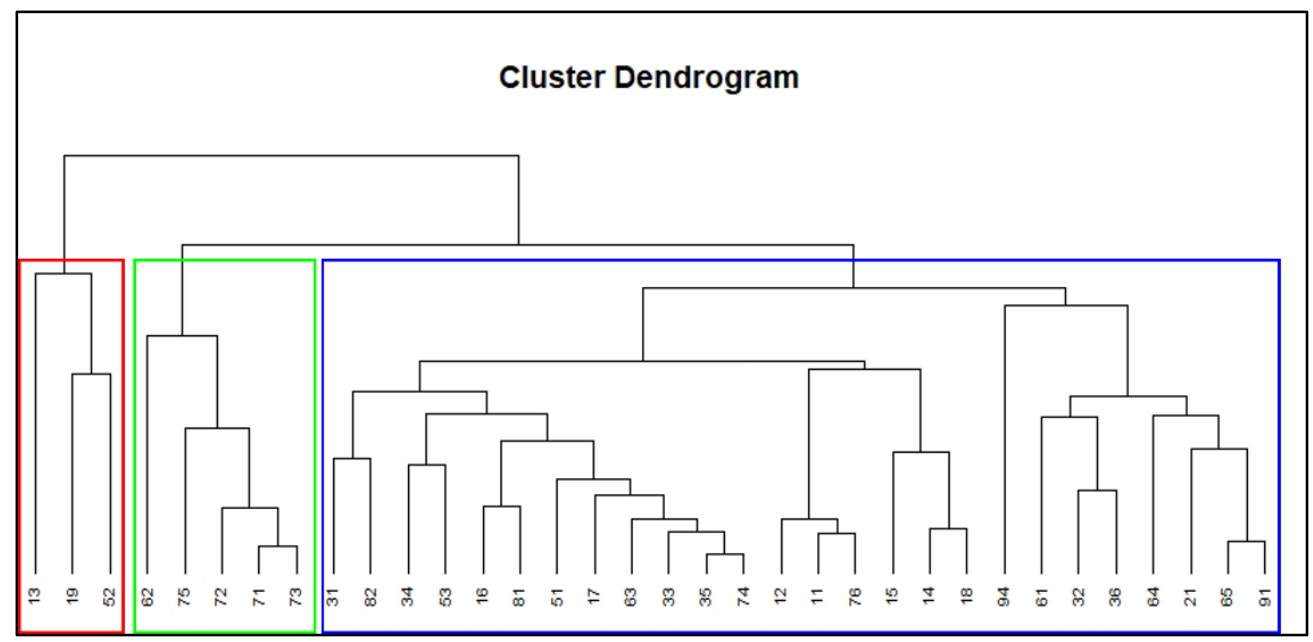

Gambar 4. Dendrogram Hasil Clustering Provinsi di Indonesia Berdasarkan Komponen IDG.

Gambar 4 yang berisikan dendrogram hasil clustering menunjukkan bahwa ada tiga klaster IDG di Indonesia berdasarkan komponen penyusunnya. Angka yang tertera pada dendrogram merupakan kode wilayah dari setiap provinsi. Klaster pertama adalah Sumatera Barat (13), Kepulauan Bangka Belitung (19), dan Nusa Tenggara Barat (52). Klaster kedua adalah Kalimantan Tengah (62), Gorontalo (75), Sulawesi Tengah (72), Sulawesi Utara (71), dan Sulawesi Selatan (73). Klaster ketiga adalah DKI Jakarta (31), Maluku Utara (82), D.I. Yogyakarta (34), Nusa Tenggara Timur (53), Sumatera Selatan (16), Maluku (81), Bali (51), Bengkulu (17), Kalimantan Selatan (63), Jawa Tengah (33), Jawa Timur (35), Sulawesi Tenggara (74), Sumatera Utara (12), Aceh (11), Sulawesi Barat (76), Jambi (15), Riau (14), Lampung (18), Papua (94), Kalimantan Barat (61), Jawa Barat (32), Banten (36), Kalimantan Timur (64), Kepulauan Riau (21), Kalimantan Utara (65), dan Papua Barat (91).

Visualisasi untuk melihat distribusi klaster IDG berdasarkan komponen penyusunnya dapat dilihat pada Gambar 5. 


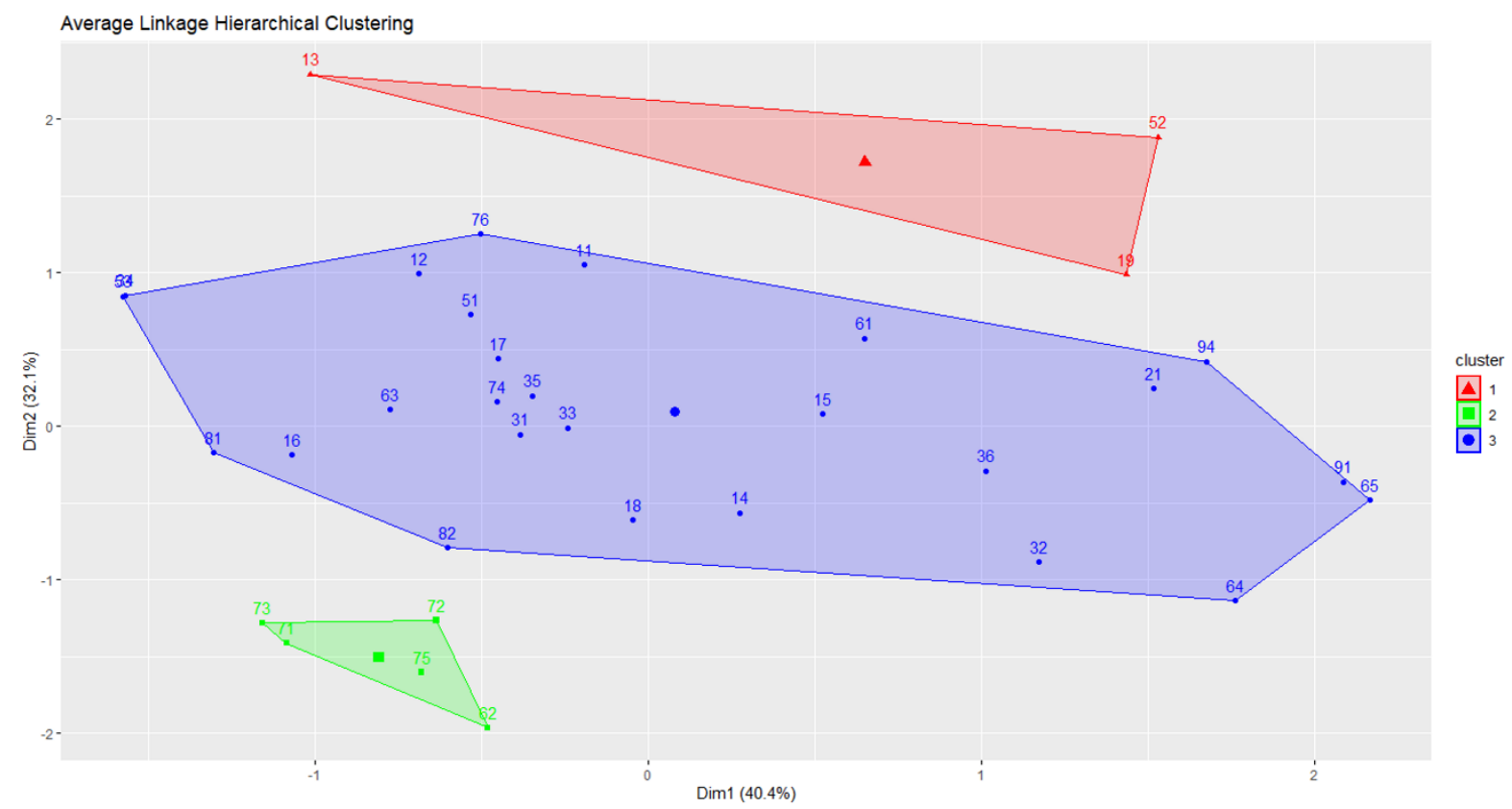

Gambar 5. Peta Cluster Provinsi di Indonesia Berdasarkan Komponen IDG.

Setelah dilakukan clustering data IDG berdasarkan komponen penyusunnya terhadap provinsi di Indonesia, maka dilakukan analisis dengan metode biplot untuk mendukung hasil pengelompokan yang telah dilakukan. Hasil dari biplot dapat dilihat pada Gambar 6.

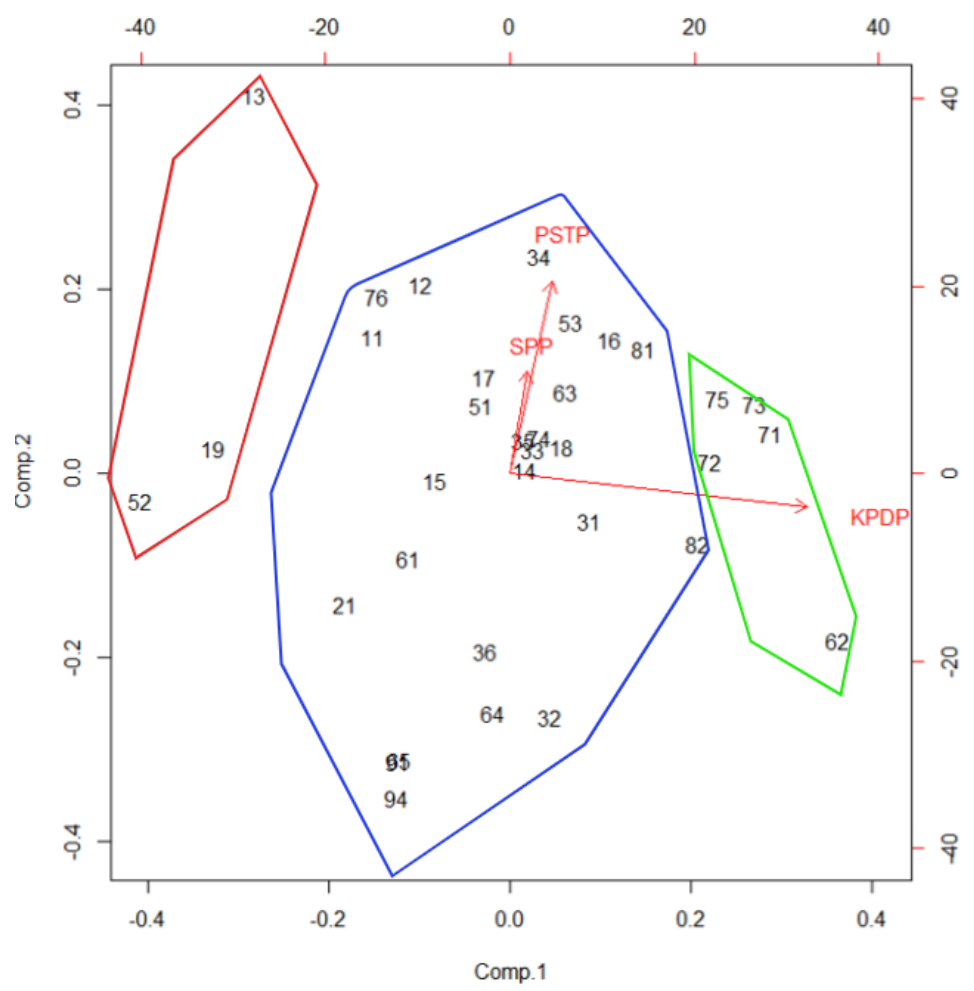

Gambar 6. Biplot Clustering Provinsi di Indonesia Berdasarkan Komponen IDG.

Berdasarkan hasil biplot yang ditunjukkan pada Gambar 6, dapat diketahui bahwa nilai komponen IDG Indonesia membentuk berbagai kelompok. Jika dilihat berdasarkan kedekatan panah, komponen Perempuan Sebagai Tenaga Profesional (PSTP) memiliki korelasi yang kuat dengan komponen Sumbangan Pendapatan Perempuan (SPP). Adapun Komponen Keterwakilan Perempuan Dalam Parlemen (KPDP) memiliki korelasi yang lemah dengan komponen Perempuan Sebagai Tenaga Profesional (PSTP) dan komponen Sumbangan Pendapatan Perempuan (SPP).

Untuk mengetahui berbagai nilai dalam komponen IDG, dapat dilihat dari panjang vektor setiap komponen. Dari visualisasi yang ditampilkan pada Gambar 6 kontribusi pendapatan perempuan memiliki 
variasi atau ragam nilai yang terkecil dibandingkan dengan dua komponen lainnya. Sementara, komponen keterwakilan perempuan dalam parlemen memiliki keragaman yang terbesar. Hal ini menunjukkan bahwa ketimpangan gender dalam mengisi parlemen pada setiap provinsi di Indonesia masih cukup besar.

Dari hasil visualisasi menggunakan biplot, dapat dilihat bahwa posisi kedekatan objek yang direpresentasikan dengan kode provinsi, memiliki hasil pengelompokan yang dekat dan mirip dengan hasil klaster yang telah dilakukan sebelumnya. Berdasarkan posisi provinsi pada variabel dan hasil pengelompokan menggunakan hierarchical clustering, klaster IDG dan karakteristik klaster berdasarkan komponen penyusunnya terhadap provinsi di Indonesia adalah sebagai berikut.

a. Kelompok pertama yang ditandai dengan warna merah terdapat tiga provinsi yaitu Provinsi Sumatera Barat (13), Kepulauan Bangka Belitung (19), dan Nusa Tenggara Barat (52). Pada kelompok pertama ini memiliki kedekatan dan karakteristik yang hampir sama, dilihat dari posisi objek yang cenderung terletak pada sisi kiri visualisasi biplot yang jauh dan ke arah yang berbeda dari vektor komponen IDG. Sehingga dapat disimpulkan bahwa kelompok pertama ini memiliki nilai komponen IDG yang rendah jika dibandingkan dengan kelompok lain, terutama dari sisi komponen keterwakilan perempuan dalam parlemen.

b. Kelompok kedua yang ditandai dengan warna hijau terdiri dari Provinsi Kalimantan Tengah (62), Gorontalo (75), Sulawesi Tengah (72), Sulawesi Utara (71), dan Sulawesi Selatan (73). Posisi objek pada kelompok ini dalam visualisasi biplot berada di sisi kanan visualisasi, dan cenderung dekat dengan vektor komponen KPDP, PSTP, dan SPP. Salah satu ciri yang menonjol dari kelompok ini adalah lebih banyaknya keterwakilan perempuan dalam parlemen dibandingkan provinsi lain di Indonesia. Dapat disimpulkan bahwa kelompok kedua memiliki nilai komponen IDG yang paling tinggi dibandingkan dengan kelompok lain.

c. Kelompok ketiga yang ditandai warna biru terdiri dari Provinsi DKI Jakarta (31), Maluku Utara (82), D.I. Yogyakarta (34), Nusa Tenggara Timur (53), Sumatera Selatan (16), Maluku (81), Bali (51), Bengkulu (17), Kalimantan Selatan (63), Jawa Tengah (33), Jawa Timur (35), Sulawesi Tenggara (74), Sumatera Utara (12), Aceh (11), Sulawesi Barat (76), Jambi (15), Riau (14), Lampung (18), Papua (94), Kalimantan Barat (61), Jawa Barat (32), Banten (36), Kalimantan Timur (64), Kepulauan Riau (21), Kalimantan Utara (65), dan Papua Barat (91). Dari visualisasi biplot, kode-kode provinsi dalam klaster ini cenderung berada di tengah dari ketiga komponen nilai IDG. Hal tersebut dapat diartikan bahwa kelompok ini memiliki nilai yang tidak terlalu tinggi dan tidak terlalu rendah baik pada komponen keterwakilan perempuan dalam parlemen, perempuan sebagai tenaga profesional dan sumbangan pendapatan perempuan.

\section{KESIMPULAN}

Berdasarkan kajian yang telah dilakukan terhadap Indeks Pemberdayaan Gender di Indonesia dapat diketahui bahwa meskipun terjadi pandemi Covid-19 pada tahun 2020, nilai IDG di Indonesia tetap mengalami kenaikan dibandingkan tahun sebelumnya. Namun, kenaikan nilai IDG yang dihasilkan pada tahun 2020 tidak sebesar kenaikan nilai IDG pada tahun 2019 sebelum terjadinya pandemi Covid-19. Jika dilihat dari tiap komponen penyusun IDG, peningkatan paling tinggi pada tahun 2020 terdapat pada komponen perempuan sebagai tenaga profesional yang naik sebesar 1,3 persen, disusul oleh komponen keterwakilan perempuan dalam parlemen yang naik sebesar 0,57 persen, dan komponen sumbangan pendapatan perempuan yang naik sebesar 0,16 persen dari tahun 2019. Pada tahun 2020 hanya terdapat lima provinsi yang memiliki nilai IDG di atas nilai IDG nasional, sedangkan 29 provinsi lainnya masih memiliki nilai IDG di bawah nilai IDG nasional. Hasil clustering IDG di Indonesia dengan agglomerative hierarchical clustering didapatkan tiga klaster IDG berdasarkan komponen penyusun IDG. Jika dilihat dari hasil biplot diketahui bahwa klaster pertama yang terdiri dari 3 provinsi memiliki nilai komponen IDG yang rendah jika dibandingkan dengan kelompok lain, terutama dari sisi komponen keterwakilan perempuan dalam parlemen. Klaster kedua yang terdiri dari 5 provinsi memiliki nilai tinggi pada komponen keterwakilan perempuan dalam parlemen dan merupakan provinsi yang memiliki nilai IDG di atas IDG nasional. Adapun klaster ketiga yang terdiri dari 26 provinsi memiliki nilai yang tidak terlalu tinggi dan tidak terlalu rendah pada ketiga komponen IDG. Berdasarkan hasil analisis tersebut, dapat dilihat provinsi mana yang membutuhkan perhatian khusus dari pemerintah, terutama dalam membuat kebijakan yang tanggap terhadap gender di Indonesia khususnya di tengah pandemi Covid-19 baik pada bidang ekonomi, politik dan sosial. Meskipun banyak sektor yang terdampak pandemi Covid-19, upaya pemberdayaan perempuan dapat dilakukan dengan pemberian stimulus usaha seperti dengan menyelenggarakan pelatihan terkait Usaha Mikro, Kecil, dan Menengah (UMKM) yang berpotensi baik pada masa pandemi Covid-19 dan memberikan kemudahan dalam mengakses modal usaha. 
Upaya lainnya dapat dilakukan dengan menetapkan kebijakan untuk mempertahankan proporsi gender yang seimbang serta melakukan penguatan terhadap perlindungan hukum bagi para pekerja perempuan. Peningkatan kesetaraan dalam pemberdayaan gender tidak hanya menjadi tugas pemerintah, tetapi juga tugas bersama oleh para pengusaha, masyarakat dan komunitas di Indonesia.

\section{DAFTAR PUSTAKA}

Agusrawati, Wibawa, G. N., Yahya, I., \& Abapihi, B. (2021). Biplot and Cluster Analyses to Describe Some Infectious Diseases in Southeast Sulawesi. Journal of Physics: Conference Series, 1899, 1-8.

Badan Pusat Statistik. (2020). Analisis Isu Terkini 2020. Jakarta: BPS RI.

Badan Pusat Statistik. Gender. Dipetik Juli 21, 2021, dari Badan Pusat Statistik: https://www.bps.go.id/subject/40/gender.html\#subjekViewTab2

Bappenas. (2019, Desember 9). Sekilas SDGs. Dipetik Juli 21, 2021, dari http://sdgs.bappenas.go.id/sekilassdgs/

Chairani, I. (2020, Juli). Dampak Pandemi Covid-19 Dalam Perspektif Gender di Indonesia. Jurnal Kependudukan Indonesia, 39-42.

Diana, R. (2018, Juni). Analisis Ketimpangan Gender di Provinsi Sumatera Barat. Jurnal Kependudukan Indonesia, 13(1), 55-66.

European Commission. (2021). 2021 Report on Gender Equality in the EU. Luxembourg: Publication Office of the European Union.

Fadliana, A. (2015). Penerapan Metode Agglomerative Hierarchical Clustering untuk Klasifikasi Kabupaten/Kota di Provinsi Jawa Timur Berdasarkan Kualitas Pelayanan Keluarga Berencana. Skripsi, Universitas Islam Negeri Maulana Malik Ibrahim, Malang.

Johnson, R. A., \& Wichern, D. W. (2007). Applied Multivariate Statistical Analysis 6th Edition. Upper Saddle River, New Jersey 07458: Pearson Education, Inc.

KPPA. (2020). Pembangunan Manusia Berbasis Gender 2020. Jakarta: Kementrian Pemberdayaan Perempuan dan Perlindungan Anak.

Nisa, A. H. (2018). Pengelompokkan Kabupaten/Kota di Jawa Timur Berdasarkan Kondisi Disparitas Pembangunan Manusia Berbasis Gender. Tugas Akhir, Institut Teknologi Sepuluh Nopember, Surabaya.

Situngkir, D. I., Rachmawati, E., \& Maharani, W. (2013). Analisis dan Implementasi Hierarchical Agglomerative Clustering pada Dokumen Berita Berbahasa Indonesia. Fakultas Teknik Informatika. Bandung: Universitas Telkom.

Widyadhana, D., Hastuti, R. B., Kharisudin, I., \& Fauzi, F. (2021). Perbandingan Analisis Klaster K-Means dan Average Linkage untuk Pengklasteran Kemiskinan di Provinsi Jawa Tengah. PRISMA, Prosiding Seminar Nasional Matematika 4, (hal. 584-594). 